\title{
Forebygging gjennom
}

\section{begrensning av tilgangen til selvmordsmidler}

Ved Lars M ehlum

\begin{abstract}
Tilgang til selumordsmidler er en risikofaktor for selvmord som ofte blir undervurdert. Ved å begrense slik tilgang kan vi imidlertid oppnå betydelige forebyggingseffekter. Denne artikkelen gir en oversikt over de viktigste innsatsområdene for forebygging ved begrensning av tilgangen til selumordsmidler og diskuterer hvilke erfaringer man har høstet i Norge og andre land.
\end{abstract}

I strategier for selvmordsforebygging $\mathrm{i}$ $\mathrm{N}$ orge og andre land har man som regel hovedfokuset rettet mot individer eller grupper med økt risiko for suicidal atferd. Slike høyrisikostrategier har sin solide begrunnelse i kunnskaper om risikofaktorer for selvmord ervervet giennom forskning og praksis på en rekke områder. Eksempelvis har sammenhengen mellom psykiske lidelser og selvmordsrisiko vist seg å være sterk. Likevel kan ikke forebygging rettet mot psykisk uhelse alene Iøse samfunnsproblemet selvmord. I øø ge analyser fra W H O kan vi bare regne med et sammenlagt forebyggingspotensial på om lag $20 \%$ ved optimal reduksjon i selvmordsrisken knyttet til de psykiske lidelsene depresjon, schizofreni og al koholisme (Bertolote et al, 2003). D et er lett å tenke seg at risikofaktorer av mindre sentral betydning vil ha et tilsvarende svakere forebyggingspotensial. Vi trenger derfor flere tilnærminger til selvmordsforebygging - gjerne i kombinasion - slik at større effekt kan oppnås ved at de ulike tiltakene virker sammen. Tiltak som begrenser tilgangen til selvmordsmidler, er en slik alternativ tilnærming til selvmordsforebygging. $\mathrm{H}$ er er vi inne på et viktig og gan ske omfattende felt som inneholder mange praktiske tiltak som kan gi reduksjon av selvmordsraten. I denne artikkelen skal vi se nærmere på noen av de viktigste mulighetene og hvilke erfaringer vi har hatt med slik forebygging.

\section{Mekanismen ved metodebegrensning}

Begrensninger $i$ tilgangen til selvmordsmetoder har sin forebyggende effekt ved å gripe inn langt ute i selvmordsprosessen (figur 1). Det er nettopp ved à analysere prosesser og hendelsesforløp som leder fram til en selvmordshandling at man i et skadeforebyggende perspektiv søker å finne fram til praktiske forebyggingsmuligheter. Pioneren innen dette forebyggingsfeltet var den amerikanske legen og ingeniøren William H addon jr. (1926-1985) som har gitt oss mange av de begrepene og metodiske tilnærmingene vi bruker i dag.

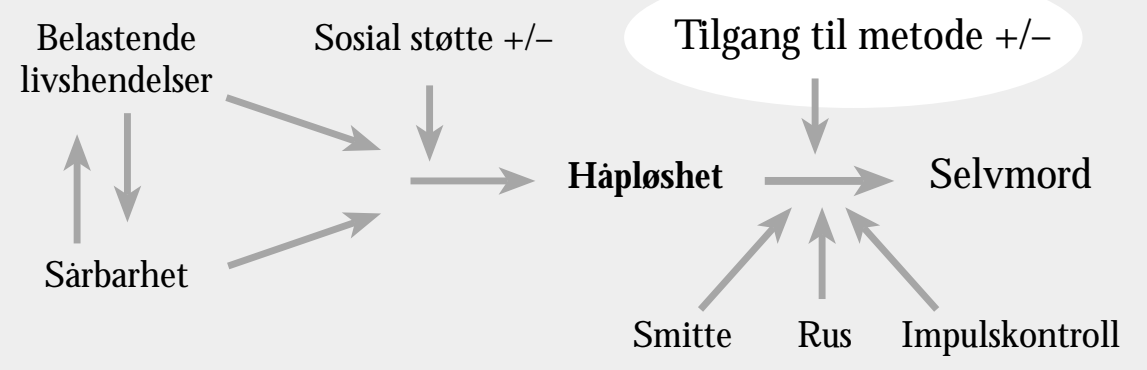

Figur 1. Selvmordsprosessen (Mehlum, 1999).
$\mathrm{H}$ addon arbeidet mye med forebygging av trafikkskader, men hans metoder har fått vidtrekkende betydning på en rekke områder og har også stor relevans for selvmordsforebygging. $\mathrm{H}$ an beskrev blant annet skadetrekanten beståen de av verten (den personen som blir skadet), det skadelige agens ( gjenstanden eller personen som forårsaker skaden) og miljøet (der skaden finner sted). Videre beskrev han skadeprosessen i tre faser; før, under og etter hendelsen som medfører skade. Basert på disse seks dimensjonene skapte han så det vi i dag kjenner som H addons matrise (1980), der tiltak som påvirker personen, det skadelige agens eller miljøet kan innføresfør, under eller etter at skaden er et faktum. I tabell 1 har vi laget et eksempel på bruk av denne matrisen i forhold til forebygging av selvmord ved bruk av giftige medikamenter. $\mathrm{H}$ addon har også beskrevet ti viktige strategier for skadeforebygging

\section{Før}

Person Gi informasjon om betydningen av å søke hjelp for psykiske problemer

A gens Reduksjon i pakningsstørrelser

Miljø Informere pårørende om risiko og risikosignaler
(1973), og i tabell 2 (s.4) er disse listet opp sammen med noen eksempler på hvordan de kan anvendes innen selvmordsforebygging.

\section{Forebyggingspotensial}

Ved utvikling av selvmordsforebygging i tråd med den skadeforebyggende modellen er det, som ved all annen forebygging, nyttig å kjenne til de epidemiologiske forhol dene på feltet. I denne sammenheng er vi opptatt av hvor vanlig bruk av de ulike selvmordsmetodene er i geografiske områder og i ulike deler av befolkningen. $\mathrm{H}$ er er det ganske store variasjoner. Eksempelvis skjer mer enn $60 \%$ av alle selvmord i U SA ved bruk av skytevåpen, mens få ( mindre enn $5 \%$ ) tar sitt eget liv ved hjelp av landbruksgifter (C enters for Disease $\mathrm{C}$ ontrol, 2004). Til sammenlikning skjer nærmere $60 \%$ av alle selvmord $i$ Kina ved anvendelse av landbruksgifter, mens mindre enn $5 \%$ av selvmordene
Tabell 1. H addons matrise med eksempelet forebygging av selvmord ved forgiftning med medikamenter. 


\section{ST RATEG I}

1. Eliminere risikoen

2. Separere risikoen

3. Isolere risikoen

4. M odifisere risikoen

5. U truste for å tåle risikoen

6. Trene og instruere

7. A dvare mot risikoen

8. O vervåke

9. Redde

\section{EKSEMPEL}

Forby salg av de giftigste plantevernmidlene

Innføre karenstid ved våpenerverv

Påby bruk av låsbare våpenskap

Bruk av katalysatorer i bilmotorer (redusere $\mathrm{C} O$ utslipp)

Gjennomføre mestringsorienterte programmer for skoleelever

G jennomføre førstehjel pskurs ved sel vmordsfare

G jennomføre opplysningskampanjer rettet mot publikum

Etablere rapporteringssystemer for selvmordsforsøk

Etablere kriseintervensjonstiltak

Tilby behandling og oppfølging for selvmordsforsøkere

\section{Tabell 2. H addons 10 skadeforebyggende strategier med eksempler fra}

\section{selvmordsforebygging.}

skjer ved bruk av skytevåpen (Phillips et al, 2002).

Dette henger naturligvis sammen med at de ulike selvmordsmidlene er svært

ulikt tilgjengelig i de to land. Det medfører også at potensialet for forebygging altså hvor mange selvmord som kan forhindres - er svært forskjellig i de to land i forhold til begrensninger i tilgang til de samme sel vmordsmetoder. I N orge likner situasjonen mer på den de har i U SA .

En oversikt over ulike selvmordsmetoder og forebyggingspotensial i N orge er gitt av G jertsen i dette nummeret av

Suicidologi (se s. 8ff.).

Ved bruk av en skadeforebyggende modell som beskrevet ovenfor, kan vi tenke oss i alle fall tre innfallsvinkler til forebygging. For det første handler det om begrensninger i tilgangen til selvmordsmidlene. For det andre gjelder det å redusere dødeligheten av selvmordsmidlene. Endelig kan det være aktuelt å begrense utbredelsen av kunnskaper om selvmordsmetoder. Vi vil ta for oss alle disse tre innfallsvinklene i den videre presentasjonen av ulike skadeforebyggende tiltak og hvilke erfaringer man har høstet.

\section{Skytevåpen, selvmord og forebygging}

Forskning har vist at det er en sammenheng mellom det å ha skytevåpen i hjemmet og sannsynligheten for at ett av husstandens medlemmer skal ta sitt eget liv ved hjelp av skytevåpen (Brent, 2005) . Det er ikke bare personer som har en påvisbar psykisk lidelse som har en slik økt risiko forbundet med å oppbevare skytevåpen i hjemmet. Det gjelder også til- synelatende friske personer. Det er også vist at risikoen er særlig stor i forhold til yngre personer og i det første året etter våpenkjøpet. Videre er det større risiko forbundet med å ha et håndvåpen (sammenliknet med å ha et gevær) i husstanden. Ladde våpen og vápen som ikke er nedlåst, medfører større risiko enn våpen som oppbevares atskilt fra ammunisjon og/eller er nedlåst (H estetun, 2004). I en $\mathrm{H}$ addonsk tenkning er det klart at det kan finnes en rekke an grepspunkter for forebygging ut fra de fakta om skyteselvmord som her er nevnt. $M$ an har vært særlig opptatt av lovgivning for å begrense utbredelsen av skytevåpen i samfunnet. $\mathrm{N}$ oen lover krever gyldig grunn for at bæretillatelse skal innvilges. A ndre setter al dersgrenser for våpenerverv eller de krever opplæring før tillatelse blir gitt. Enkelte land har også innført karenstid mellom søknad om våpenerverv og utlevering av våpen. Flere studier har vist at slik lovgivning kan ha en forebyggende effekt, blant annet i en canadisk studie av utviklingen etter innføring av restriktive lover i delstaten O ntario i 1978

(C arrington et al, 1994). Etter vedtak av nye våpenlover i N ew Zealand i 1993

fant man tilsvarende en sterk reduksjon i selvmordsraten ved skyting (Beautrais, 2004). I N orge er slike forebyggingserfaringer særlig interessante fordi så mange husstander (om lag $30 \%$ ) i vårt land har ett eller flere skytevåpen, og fordi så mange selvmord skjer ved bruk av skytevåpen. O gså i N orge har man skjerpet lovgivningen både når det gjelder våpenerverv, ved innføring av karenstid og når det gjelder oppbevaring. Videre har man spredd informasjon til våpenbrukere (jegere) om betydningen av sikker våpenoppbevaring (H estetun, 2004). I det norske Forsvaret har man nylig gått en da lenger ved å inndra mange av beredskapsvåpnene og ved å fjerne tennstempler i $\mathrm{H}$ eimevernets geværer. Det kan ikke utelukkes at den betydelige reduksjonen som er observert i selvmordsraten ved skyting blant menn fra 1987 ( $11.0 / 100000)$ til 2002 (4.6/ $100000)$, har en sammenheng med disse forebyggende tiltakene. I 1987 utgjorde skyteselvmord $39 \%$ av alle selvmord blant norske menn, mens den tilsvarende andelen var $24 \%$ i 2002. Blant kvinner er det hel digvis meget få selvmord ved skyting.

\section{Medikamenter og forgiftning}

I mange land er forgiftning den vanligste selvmordsmetoden blant kvinner. I femårsperioden 1999-2003 utgjorde forgiftning $36 \%$ av alle selvmord blant norske kvinner (Statistisk sentral byrå, 2005). B lant menn skjer det også mange selvmord ved forgiftning, men den prosentvise andelen er betydelig lavere.

M edikamenter er i stadig økende bruk i befolkningen og finnes i nær sagt alle hjem. Her er det derfor et stort forebyggingspotensial, noe som har fått flere land til å innføre begrensninger i pakninger og doser særlig av smertestillende medikamenter som kan fås kjøpt uten resept. Videre har man innført bruk av blisterpakninger, som har den fordel at de hindrer personer i å tømme et pilleglass ved en impulshandling. I en grundig studie utført av $\mathrm{H}$ awton og medarbeidere (2001) i 0 xford, kartla man en rekke forhold før og etter at det ble innført begrensninger på sal get av paracetamolpreparater i England og W ales i 1998. M an observerte en rekke gunstige virkninger av lovendringen; en signifikant reduksjon ( $21 \%$ ) i antall dødsfall ved forgiftning med para-

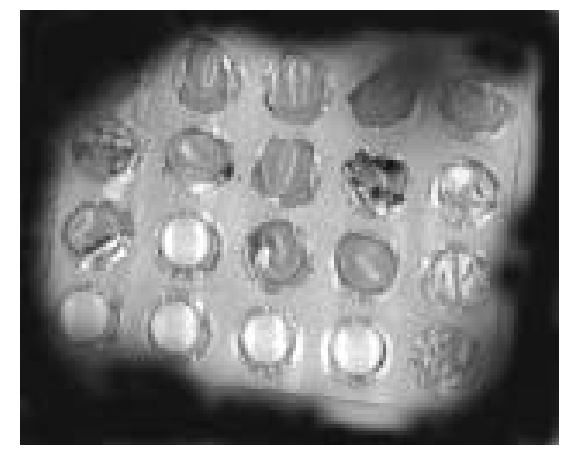


cetamol, en signifikant reduksjon i antall ikke-dødelige forgiftninger ( $11 \%$ ) og en signifikant reduksjon i antall personer som fikk utført levertransplantasjon etter ødeleggelse av leveren ved paracetamolforgiftning. Liknende erfaringer er gjort i en rekke andre land. I dette perspektivet er det beklagelig at N orge har beveget seg i motsatt retning og løsnet opp på begrensningene i paracetamolsalget ved at man nå kan få kjøpt slike medikamenter i dagligvarehandelen.

G jennom årene har endringer i egenskapene ved og salget av vanlig brukte legemidler påvirket forgiftningspanoramaet betydelig. Barbiturater, som tidligere var hyppige forgiftningsmidler, er nesten forsvunnet fra statistikkene. Selvpåført forgiftning med trisykliske antidepressiver, som tidligere tok mange liv, har blitt stadig sjeldnere i takt med at de nyere SSRIpreparatene har tatt over som førsteval gspreparat i den medikamentelle behandlingen av depresjon. SSRI-preparatene har en betydelig lavere giftighet enn de trisykliske antidepressivene og er derfor langt tryggere i bruk.

\section{Andre giftige stoffer}

Som nevnt ovenfor er landbruksgifter av svært stor betydning som risikofaktor for selvmord i en global sammenheng selv om de betyr lite i N orge og andre vestlige land. A v Kinas om lag 290000 selvmord pr år (Phillips et al, 2002) (som er nærmere $30 \%$ av det estimerte samlede tallet av sel vmord i verden) skjer om lag 2/3 ved bruk av landbruksgifter. $M$ ange av disse selvmordene er utført av unge mennesker, ikke minst av jenter, og skjer ofte impulsivt og uten at det foreligger noen påvisbar psykisk lidelse hos personen. Slik sett kan disse tilfellene minne om mange medikamentforgiftninger hos ung-

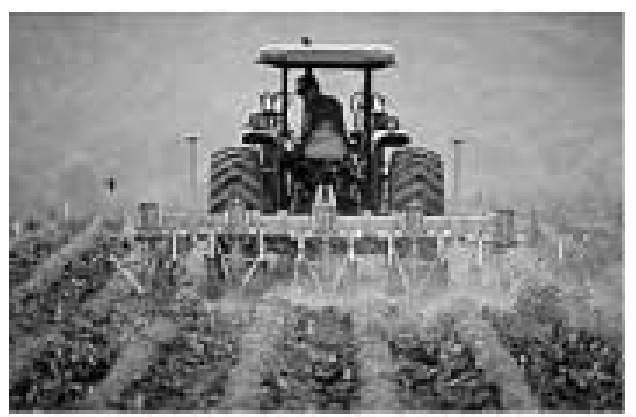

dommer i Vesten. M en medikamentene som disse vestlige ungdommene tar, er ofte mye mindre giftige, og dermed er det bare et mindretall som dør av forgiftningen. I de fleste vestlige land er de farligste landbruksgiftene blitt forbudt og er erstattet av nye stoffer som er tryggere i bruk. $M$ en siden disse nyere stoffene er betydelig dyrere å anskaffe, har de ikke vunnet fram i utviklingslandene. En kan tenke seg en rekke ulike tilnærminger til å forebygge selvmord ved bruk av landbruksgifter. Politiske tiltak gjennom internasjonale avtaler om forbud eller begrenset bruk eller tiltak utviklet i FN -systemet ( W H O , FA O), har vært drøftet. Skal fattige land ha mulighet til å forby de giftigste stoffene, vil de trolig trenge omfattende økonomisk bistand. På kort sikt har man derfor prioritert å drive opplysningsvirksomhet, holdningsskapende arbeid og arbeide for å få innført sikrere oppbevaring av landbruksgiftene slik at barn og ungdommer ikke så lett får fatt i dem når de er i en emosjonell krise. Den internasjonale foreningen for selvmordsforebyggende arbeid (IA SP) har satt fokus på dette i den senere tid.

I vestlige land har giftige gasser, slik som husholdningsgass og bileksos, hatt en langt større betydning for selvmordsratene enn landbruksgifter. I England og $W$ ales var husholdningsgass den vanligste selvmordsmetoden både blant kvinner og menn fram til begynnelsen av 1960tallet. $G$ assen ble fremstilt på basis av kull og inneholdt store mengder karbonmonoksyd. M en da man fant olje og gass i $\mathrm{N}$ ordsjøen, ble kullgassen gradvis erstattet av naturgass med lavt C O-innhold. I årene som fulgte, ble sel vmord ved bruk av husholdningsgass stadig mindre vanlig og er nå fullsten dig borte fra statistikkene ( M c Clure, 2000). Bare gradvis og langsomt skjedde det en overgang til andre metoder, al tså at risikoutsatte i stedet benyttet andre selvmordsmidler. Dermed ble mange tusen menneskeliv spart i England og W ales i disse årene. Tilsvarende erfaringer er gjort i land som U SA, Tyskland, Japan, Sveits og N ederland.

Bruk av bileksos er en selvmordsmetode av stort omfang i mange land. Katalysatorer reduserer som kjent innholdet av karbonmonoksyd i bileksosen og reduserer dermed giftigheten av gassen Flere studier har rapportert en reduksjon i forekomsten av slike selvmord etter at katalysatorer ble innført av miljømessige hensyn. (M ott et al 2002). M an har også diskutert muligheten av å redusere antall selvmord ved bruk av bileksos ved å endre formen på eksosrøret slik at det ikke skal være så lett å feste en slange til røret. Videre har man diskutert om det ikke bør påbys å installere mekanismer i nye biler som sørger for at bilmotoren skrus av dersom $\mathrm{CO}$-innholdet i bilkupéen stiger over et visst nivå.

\section{Faren ved alkohol}

A lkohol er involvert i en stor andel av alle selvmord, både i $\mathrm{N}$ orge $\mathrm{og}$ andre land (M urphy, 1992; Rossow, 1997). Til tross for at alkohol trolig ikke er så vanlig i bruk som selvmordsmiddel i seg selv, spiller alkoholen en sentral rolle i selvmordsprosessen i mange tilfeller. A lkoholbruk reduserer ofte impulskontroll og dømmekraft, og bidrar til at langt flere enn alkoholikere kommer i risikosonen for å utføre selvdestruktive handlinger når de er i emosjonell ubalanse. N oen ganger blir bruken av alkohol en del av selvmordshandlingen ved at personen drikker for å få mot til å utføre den. Potensial et for forebygging av selvmord ved reduksjon i tilgangen til alkohol er betydelig.

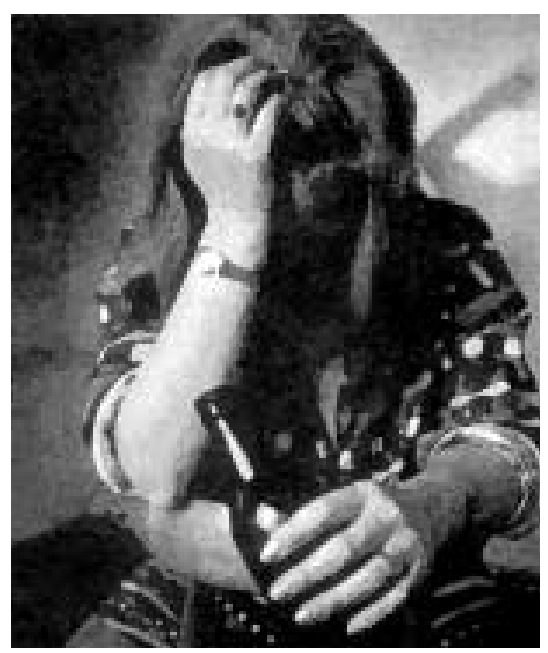

Sammenhengen mellom reduksjon i slik tilgang og reduksjon i selvmordsraten er demonstrert i en rekke land. U nder forbudstiden i U SA (1910-1920) falt selvmordsraten betydelig (W asserman, 1992). Det samme skjedde på om lag samme tid i Danmark (1911-1921) da man innførte 
en sterk prisøkning på alkohol. U nder "motbok"-tiden i Sverige (1915-1955) hadde man tilsvarende erfaringer. "M otboken" var et alkoholrasjoneringssystem som medførte en betydelig reduksjon i alkoholkonsumet i den svenske befolkning så lenge ordningen varte (W illner, 2005). Den kanskje best dokumenterte sammenheng mellom alkoholbruk og selvmordsrate i samfunnet er rapportert av Värnik \& W asserman (1993) på basis av erfaringene med den restriktive alkoholpolitikken som ble innført i Sovjetunionen under G orbatsjovs Perestroijka (1984-86). Denne politikken var meget ambisiøs og innebar blant annet kutt i alkoholproduksjonen ved nedleggelse av vinmarker og brennerier. Det ble innført prisøkning og salgsrestriksjoner slik at hver voksen person maksimalt fikk kjøpe 0,5 liter vodka eller annen tilsvarende alkoholholdig drikk per måned. Bedriftsog institusjonsledere ble pålagt å drive holdningsskapende arbeid. M an styrket tilgangen på tilbud om avrusning, behandling og rehabilitering av alkoholmisbrukere. Endelig ble det innført strenge reaksjoner overfor alkoholmisbruk - slik som økt bruk av arrestasjon og bøtelegging. Ved stadig gjentakelse av misbruk ble arbeidsgiver orientert og man risikerte oppsigelse fra jobben. M an kan lett tenke seg at disse tiltakene var forholdsvis lite populære blant mange sovjetinnbyggere, men de ble ledsaget av en signifikant reduksjon i selvmordsraten i alle de 15 sovjetrepublikkene. Reduksjonen blant menn var på hele $40 \%$. Etter at denne restriktive politikken ble avskaffet på slutten av 1980-tallet steg både alkoholkonsumet og selvmordsratene igjen (Värnik \& W asserman, 1993).

\section{Hopp fra høye steder}

Det kan trygt sies at $\mathrm{N}$ orge er et land som byr på mange muligheter når det gjelder selvmord ved utsprang fra høyt sted. Likevel utgjør ikke slike selvmord mer enn om lag $5 \%$ av alle selvmord (dvs. ca. 25 personer) hvert år. I andre land ser situasjonen helt annerledes ut. For eksempel har andelen av selvmord ved utsprang vært på hele 30-40 \% i $\mathrm{H}$ ong K ong og Singapore, der de fleste bor i høyhus (Yip et al, 1998). Likevel er totaltallet av selvmord ved utsprang for-

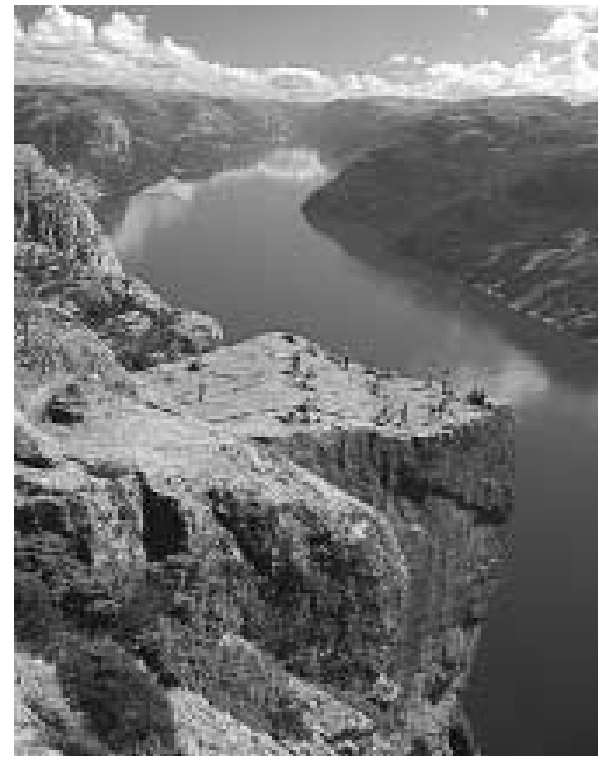

holdsvis begrenset i de fleste land. Til gjengjeld er disse sel vmordene gjerne knyttet til et fătall av steder (broer, bygninger eller naturlige høyder) som etter hvert har fått en spesiell status som selvmords steder eller "hot spots" som de kalles på engelsk. Blant dem er det mange broer, gjerne høye og spektakulære og beliggende nær befolkningssentra ( $L$ indqvist et al, 2004; G unnell et al, 2005). En av de mest berømte er $\mathrm{G}$ olden $\mathrm{G}$ ate-broen i San Francisco, der mer enn 1000 kjente tilfeller av selvmord har funnet sted. O gså i $\mathrm{N}$ orge har enkelte broer en tendens til å tiltrekke seg personer som ønsker å ta sitt eget liv. Derfor er det nå igangsatt arbeid med å sikre noen av disse broene ved å øke høyden på rekkverkene. I føl ge rapporter fra andre land kan slike tiltak trolig forebygge selvmord (Beautrais,

2001; 0 'C arroll et al, 1994). Skeptikere har innvendt at dersom én bro sikres, vil selvmordsnære personer mest sannsynlig finne seg en annen bro i nærheten. Det er likevel lite som tyder på at dette skjer - i alle fall i første omgang ( 0 'C arroll et al, 1994) - og dermed kan mange liv reddes. I en egen artikkel i dette nummeret av Suicidologi går G unnell og medarbeidere dypere inn i dette emnet og viser til evalueringer som har vært gjort (se s. 15ff.)

0 gså høye bygninger eller naturlige høyder kan være aktuelle å vurdere for sikringstiltak. Det kan synes som en umulig oppgave å skulle sikre alle bygg, trappetårn, utsiktspunkt etc. M en igjen må vi huske at ikke alle slike steder blir "hot spots" for selvmordsnære personer. Det er gjerne spektakulære eller berømte steder som făr slik status og som derfor bør sikres. D et samme gjelder høye bygg eller broer som ligger i nærheten av psykiatriske behandlingsen heter, som vist av Beautrais (2001).

\section{Kunnskaper om selvmordsmetoder}

I et historisk perspektiv har det skjedd ganske store endringer i hvilke sel vmordsmetoder som har vært mest vanlige i bruk. Slike endringer kan, som vi har sett, henge sammen med økt eller redusert tilgang til metodene eller med deres farlighet eller giftighet. $0 \mathrm{~m}$ metodene er kjent for risikoutsatte grupper, spiller naturligvis også en rolle. M edieomtale kan føre til at metoder som tidligere ikke var i bruk, øker i utbredelse. Et eksempel på dette har vi sett i H ong Kong i løpet av de seneste år der stadig flere har gjort selvmord ved å lukke seg inne på bad eller W C og tenne opp en engangsgrill - en meget farlig metode som med stor sikkerhet medfører døden ved kullosforgiftning. Denne selvmordsmetoden var helt ukjent i H ong Kong inntil 1999, men har på få år blitt en av de vanligste selvmordsmetodene. Trolighar denne utviklingen en sammenheng med en rekke sensasjonspregete oppslag i massemedia (C han et al, 2005). Liknende erfaringer er gjort i Taiwan.

I mange land skjer mange selvmord ved at personer kaster seg foran tog eller T-bane. I land som U SA, M alaysia og Singapore har man gode erfaringer med å bygge barrierer mot sporene på stasjonsområder. $\mathrm{M}$ an burde opplagt ha sikret sporene bedre også utenfor stasjon sområdene, men siden jernbanenettet er så finmasket i mange tett befolkede områder, kan dette vise seg teknisk og økonomisk vanskeligå gjennomføre. Dermed vil jernbanelinjer i mange land representere en potensiell risikofaktor for selvmord i overskuelig fremtid. Det har derfor også vist seg særlig viktig å unngå uhel dig medieomtale av jernbaneselvmord. I en velkjent tysk studie (1988) rapporterte Schmidtke og $\mathrm{H}$ äfner en klar sammenheng mellom TV-fremvisning av et slikt selvmord og påfølgende økning i denne typen selvmord i de områdene hvor TV-sendingen var blitt vist. Tilsvaren de erfaringer ble gjort i W ien etter åpningen av byens 


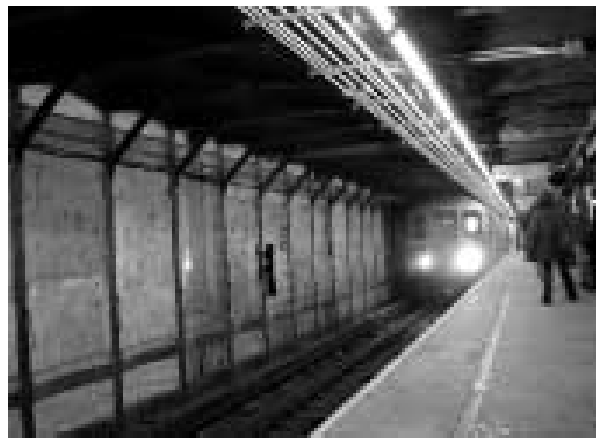

nye T-banesystem. Etter sterk mediefokusering av tilfeller av selvmord på T-banen antok denne typen selvmord epidemiske dimensjoner inntil man fikk til en avtale med pressen om ikke å omtale disse selvmordene. Da medieomtalen stoppet, falt hyppigheten av T-baneselvmord raskt (Etzersdorfer et al, 1992).

0 gså når det gjelder presseomtale av "hotspots" for selvmord, er det vanligå regne med at smitteeffekter kan formidles. Det samme gjelder for spesifikk og detaljert omtale av nær sagt alle selvmordsmetoder. Dette bør føre til at massemediene fortsatt viser stor varsomhet ved slik omtale.

Et problem av relativt ny dato er at enkelte internettsteder ikke bare omtaler konkrete tilfeller av selvmord, men også formidler rene oppskrifter og veiledninger i hvordan man enklest og sikrest kan ta sitt eget liv. Vi kjenner etter hvert til mange enkelttilfeller der slike selvmordssider ser ut til å ha bidratt til at unge mennesker har tatt sitt eget liv. Det har vist seg vanskelig å få bukt med disse nettstedene siden internettet mangler flere av de regulerende mekanismene som andre massemedier er underlagt. Likevel er det viktig å finne fram til mulige mottiltak, slik den danske journalisten Kim Engelbrechtsen skriver om i en artikkel i dette nummeret av Suicidologi (se s. 18).

\section{Konklusjon}

Selvmord er en bevisst og villet handling som fører til døden, selv om hensikten ikke alltid var å dø. Intuitivt vil vi derfor som regel forholde oss til den handlende suicidale personen direkte og forsøke å redusere sel vmordsrisikoen gjennom individrettede tiltak. M en som vi har sett, bør vi ikke glemme at begrensninger i tilgang til sel vmordsmidler har et stort forebyggingspotensial. Slik forebygging kan involvere sektorer også utenfor helsevesenet og kan ha effekter som vi ikke kan oppnå på annet vis.

Vi bør ta med oss det skadeforebyggende perspektivet også inn i våre møter med enkel tpersoner i selvmordskrise og i kliniske sammenhenger. Psykiatriske avdelinger bør vie særlig oppmerksomhet til fysiske sikringstiltak og rutiner som kan forhindre selvmord ved hengning, utsprang eller andre metoder. For hver enkelt selvmordsnære pasient bør det lages en sikkerhetsplan som viser samsvar mellom resul tatet av risikovurderinger og iverksatte sikringstiltak.

U tenfor avdeling og i møtet med selvmordsnære kan hver enkelt av oss også benytte tenkningen fra skadeforebygging. Dersom det er risiko for selvmord, bør vi alltid undersøke om vedkommende har lett tilgang til giftige medikamenter eller skytevåpen. $H$ vis dette er tilfellet, bør vi omgåen de sørge for at disse selvmordsmidlene blir brakt utenfor personens rekkevidde.

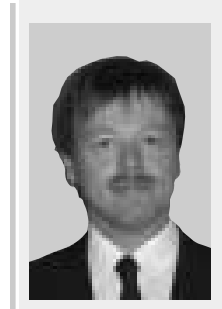

L ars Mehlum er psykiater og professor i suicidologi ved U niv. i 0 slo. $\mathrm{H}$ an er leder for SSFF og er bredt engasjert i en rekke forsknings- og forebyggingsprosjekter. $\mathrm{H}$ an har publisert flere lærebøker, samt en rekke vitenskapelige artikler.

\section{Referanser}

Beautrais A .L. (2001). Effectiveness of barriers at suicide jumping sites: a case study. A ust $N Z$ J Psychiatry, 35, 557-62.

Bertolote J.M ., Fleischmann A ., De Leo D., Wasserman D. (2003). Suicide and mental disorders: do we know enough? Br J Psychiatry, 183, 382-3.

Brent $D$. Firearms and suicide.

www.afsp.org/education/brent.htm. (30.5.05)

Carrington P.J., M oyer S. (1994). G un control and suicide in 0 ntario. A m J Psychiatry, 151, 606-8.

Centers for Disease Control. www.cdc.gov. (30.5.05)

Chan K.P., Yip P.S., A u J., Lee D.T. (2005)

$C$ harcoal-burning suicide in post-transition $\mathrm{H}$ ong Kong. Br J Psychiatry, 186, 67-73.

Engelbrechtsen K. (2005). Forby selvmordshjemmesiderne. Suicidologi, 2, 18.

Etzersdorfer E., Sonneck G., N agel-KuessS. (1992). $\mathrm{N}$ ewspaper reports and suicide. $\mathrm{N}$ ew England Journal of M edicine, 327, 502-503.

G jertsen F. (2005). D e vanligste selvmordsmetodene i $\mathrm{N}$ orge: $\mathrm{U}$ tvikling over tid med fokus på kjønn og alder. Implikasjoner for selvmordsforebygging. Suicidologi, 2, 8-10.

G unnell D., N owers M., Bennewith O. (2005) $\mathrm{K}$ an selvmord ved hopping forhindres? Suicidologi, 2, 15-17.
Haddon W. (1972). A logical framework for categorizing highway safety phenomena and activity. J Trauma, 12, 193-207.

H addon W. (1973). Energy damage and the ten countermeasure strategies. J Trauma 13, 321-31.

H addon W. (1980). A dvances in the epidemiology of injuries as a basis for public policy. Public $\mathrm{H}$ ealth Rep, 95, 411-21.

H awton K., Townsend E., Deeks J., A ppleby L., G unnell D., Bennewith O., C ooper J. (2001). E ffects of legislation restricting pack sizes of paracetamol and salicylate on self poisoning in the $U$ nited K ingdom: before and after study. BMJ, 322, 103-7.

H estetun I. (2004). Skytevåpen og forebygging av selvmord. Suicidologi, 1, 16-18.

Lindqvist P., Jonsson A ., Eriksson A ., Hedelin A ., Bjornstig U. (2004). A re suicides by jumping off bridges preventable? A $\mathbf{n}$ analysis of $\mathbf{5 0}$ cases from Sweden. A ccid A nal Prev., 36(4), 691-4.

M cClure G.M. (2000). C hanges in suicide in England and W ales, 1960-1997. Br J Psychiatry, 176, 64-7.

M ehlum, L. (red). (1999). Tilbake til livet. Selvmordsforebygging i teori og praksis. Kristiansand: $\mathrm{H}$ øyskoleforlaget.

M ott J.A ., W olfe M .I., A Iverson C.J., M acdonald S.C., Bailey C.R., Ball L.B., M oorman J.E., Somers J.H., M annino D.M ., Redd S.C. (2992). N ational vehicle emissions policies and practices and declining $U$ S carbon monoxide-related mortality. JA M A , 288, 988-95.

M urphy G.E. (1992). Suicide in alcoholism. $O$ xford: $O$ xford U niversity Press.

0 'C arroll P.W., Silverman M.M., Berman L. (1994). Community suicide prevention: The effectiveness of bridge barriers. Suicide LifeThreatening Behavior, 24, 89-99.

Phillips M .R., Li X., Zhang Y. (2002). Suicide rates in China, 1995-99. Lancet, 359, 835-40.

Rossow I. (1997). A lkohol og selvmord. Suicidologi, 2, 12-13.

Schmidtke A ., H äfner H . (1988). T he Werther effect after television films: new evidence for an old hypothesis. Psychol M ed, 18(3), 665-76.

Statistisk sentral byrå. (2005, 30. mars). Tab.9: Selvmord etter dødsmåte: 1973-2003. H entet 30.5.05 fra www.ssb.no/emner/03/01/10/dodsarsak/ tab-2005-03-30-09.html.

V ärnik A ., W asserman D. (1998). A cta Psychiatr Scand Suppl., 394,1-4.

Wasserman I.M . (1992). T he impact of epidemic, war, prohibition and media on suicide: U nited States, 1910-1920. Suicide Life Threat Behav, 22,240-54.

Willner S. A lkoholpolitik och hälsa hos kvinnor och män. www.fhi.se/upload/ar2005/rapporter/ r200508folkhal sohistoria_del5_0505.pdf. (30.5.05)

Yip P.S., Tan R.C. (1998). Suicides in H ong-Kong and Singapore: a tale of two cities. Int J SOC Psychiatry, 44(4), 267-79. 